\title{
'It is now in your hands': South Africa's dilemma for religion and governance in the changing COVID-19 context
}

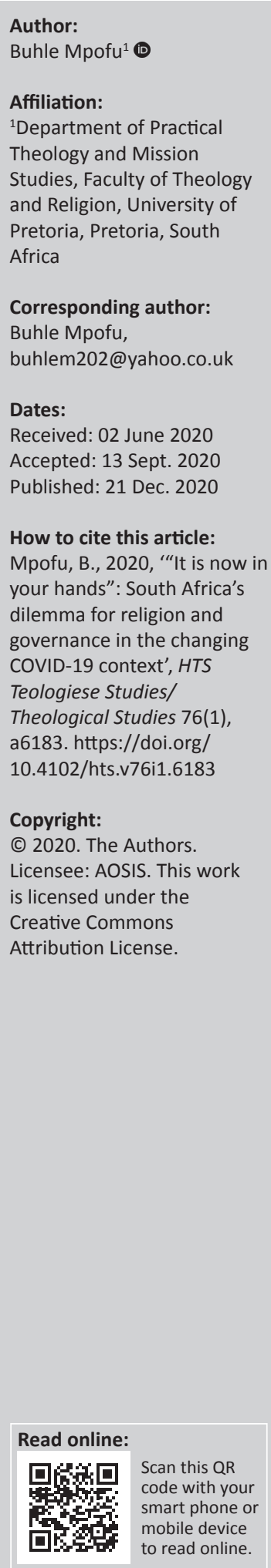

This article examines how coronavirus disease 2019 (COVID-19) impacted on religion-state relations in South Africa. By examining the models of religion-state relations the article highlights the implications of these relations in the context of the South African government's national response to COVID-19 and critically engages a public theology of 'immense trust and authority' assigned to leaders. The article identifies 'separation with interaction' as a model, which informs the South African government's state-religion engagement. Although this model is constitutional and promotes religious freedom, the article identifies the government's failure to act decisively on religious leaders who exploit the poor as a major obstacle to socio-economic and religious transformation. The article contends that the dark part of South African history presents a dilemma to church-state relations in South Africa and suggests that life-affirming practices of political and religious leaders should be tested through the values of goodness, kindness, justice and obedience as a demonstration that they are essential workers who have an important transformational role to play in the context of COVID-19.

Contribution: This article represents a systematic and practical reflection within a paradigm in which the intersection of philosophy, religious studies, social sciences, humanities and natural sciences generates an interdisciplinary, multidisciplinary and transdisciplinary contested discourse.

Keywords: COVID-19; religion and governance; state-religion models; South Africa.

\section{Introduction}

Coronavirus disease 2019 (COVID-19) has fundamentally changed the world and impacted on religious and political processes in significant ways. The rapidly changing socio-political and religious contexts will impact on the economics and politics of contemporary Africa. Addressing the nation on the 13th of May 2020, South African President Cyril Ramaphosa highlighted some of the necessary changes in life and worship practices:

There needs to be a fundamental shift in our thinking and our way of life ... [we] will need to re-organize workplaces, schools, universities, colleges and other public places to limit transmission ... We will [also] need to adapt to new ways of worshipping, socializing, exercising and meeting. (President C. Ramaphosa, 13 May 2020:6)

This fundamental shift is necessary in post-COVID-19 contexts, the new normal, as communities have to remain compliant with new regulations as part of combatting the spread of the virus. We all have to comply with the necessary - although disruptive - social-distancing measures because epidemiological evidence shows that social distancing, combined with general hygiene, and personal protective clothing are effective ways of reducing the spread of the virus.

Coronavirus disease 2019 disruptions to life activities have given a new meaning to life as business and faith communities creatively moved to 'cyber space' and 'virtual space' to continue providing services during the lockdown. The terms 'cyber space' and 'virtual space' were first coined by science fiction author Gibson (1984), and latter Dodge and Kitchin (2001) observed that virtual reality is generated through the computer's interaction with its user. Virtual reality developed rapidly in the 1990s and as computers progressed, these two words entered the English vocabulary. The second carries the prestige and load of a philosophical tradition dating back to the Middle Ages (Ryan 1999:78). Virtual reality means it is not true, but a simulation that gives the effect and

Note: Special Collection entitled COVID-19 from a Theological Perspective, sub-edited by Jerry Pillay (UP). 
essence of reality that creates a sense of presence when playing over a computer network (Strate, Jacobson \& Gibson 2003:10), and virtual reality aims to create an atmosphere where the experiences are the same as in the real world.

As religious communities adapt to the challenge of the corona virus, new ways of fellowship emerged. Priests delivered sermons, conducted worship and dispensed sacraments on various social media platforms, creating new cyber-based faith communities. The understanding of community has changed - as society has changed - and one of the catalysts for this societal transformation is technological revolution (Lord 2002:196). With the advent of COVID-19, we now have more communities that meet online. ${ }^{1}$ Cyber communities influence both individual self-identity and expression of society:

Not only do I inhabit my virtual communities to the degree that I carry around their conversations in my head and begin to mix it up with them in real life, my virtual communities also inhabit my life. I've been colonized; my sense of family at the most fundamental level has been virtualised. (Rheingold 1993:10)

Chavis Kunzmann (2002:84) identified four elements of the sense of community as (1) experience of membership,

(2) the individual feels he or she has influence in the group,

(3) members' needs are integrated and fulfilled by the community and (4) a shared emotional connection. These four elements of the sense of community resonate with aspects of the phenomenal virtual world that has emerged in the COVID-19 context. These elements also resonate with the theory of social functioning of the brain, which was developed by David Rock (2008) in his Status, Certainty, Autonomy, Relatedness and Fairness (SCARF) model of brain function in social contexts. This model is based on neuroscience research and holds that five social domains - status, certainty, autonomy, relatedness and fairness - activate similar threats and reward responses in our brain that we rely on for survival. In engaging each other, the government and religious leaders do exhibit these traits.

Business and religious leaders will have to harness technological prowess to remain relevant and effective in the new context of fighting COVID-19. Contextualisation is an important aspect for doing mission and as Koch (2017) recently reiterated:

[C]ontextualization is a way to express our specific message to new audience, packed and interpreted into a new way, so the message as the sender can be relevant, understood and adopted by the receiver. (p. 32)

Koch's (2017) salient observation is that to contextualise 'calls for reflection on what in particular a culture is, and how to contextualize it' (p. 32). What would be the

1.It is estimated that Zoom registered more accounts than any tech company durin the COVID-19 crisis. According to Nicolo (2020) there are few companies out there in the world right now that are in the world right now that are benefiting from the coronavirus quite as much as Zoom. Zoom benefited massively from the crisis, they have helped millions by extending their free trials, removing time limits for every user in China and most importantly offering their service for free to schools and educational institutions all over the world. Viewed 02 June 2020 from: https://medium.com/swlh/what-covid19-did-for-zoom-us-what-zoom-us-did-for-covid-19-c3b766a6c723. implications for these new 'cyber communities' in religionstate relations in the South African context? These implications may be critical to interrogate in future.

\section{State-Religion models in South Africa}

Under the lockdown regulations on level four and five, religious gatherings were banned and communities with access to internet moved their services to cyber space. In his address on Sunday the 24th of May, President Ramaphosa informed the nation that government was consulting with leaders of various faith communities and the Command council through virtual meetings where they discussed government's preparations for a 'differentiated approach' across the country to manage reopening of the economy alongside the unrelenting effort to save lives. After these consultations the government agreed to allow places of worship to open, subject to compliance with agreed regulations - limiting services to 50 people, sanitising places before and after services and maintaining hygiene and social distancing measures.

This meeting represented a wide range of interfaith communities and included the leadership of the South African Catholic Bishops Conference, the South African Council of Churches, the National Interfaith Council of South Africa, the Muslim Judicial Council, the Jewish Board of Deputies, the South African Hindu Maha Sabha, African Independent Churches, Charismatic or Pentecostal churches, African Traditional Faiths, the National Religious Leaders Council and the Southern African Interfaith Council were invited (MSN News, 27 May 2020). South Africa has a diverse religious population and the diverse background of representatives reflected a constitutional guarantee for freedom of religions. Therefore, in exercising its mandate, the South African government had to consult broadly with religious leaders as a means to promote religious tolerance and ensure separation of religion and politics. Coronavirus disease 2019 brought the relations between religion and politics to a new spotlight as a result of government-initiated measures to regulate religious activities as part of responding to the public health emergency posed by the virus. However, as this article suggests, the history of collusion between religion, colonialism and apartheid mirrors a dark part of South African history and presents a dilemma in church-state relations as I will demonstrate in the sections that follow.

The interface between politics and religion is still a relatively neglected field. Jeffrey Haynes' seminal work Religion and Politics in Africa (1996) attempted to fill this gap by analysing how Christianity and Islam navigated the African political landscape to establish themselves alongside the colonial project. According to Haynes (1996:24), colonial administrations attempted to employ religion tactically in their pursuit of political dominance and in South Africa this 
is well documented in the relations that the Dutch Reformed Church had with the apartheid government.

On the contrary, religion is one of the main sources of democratic energy and the main subject of democratic debate because religious and near-religious commitments and enthusiasm are crucial features of political life (Walzer 2007:155). In South Africa, religious groups and Christian organisations championed awareness campaigns against apartheid injustices and religion became a catalyst for reform. Despite collusion with institutions of injustice, such as special protection accorded to the Reformed Church through which the Afrikaner identity was forged (Desmond 2000:13), religion played a very important role in shaping the forms of all areas in the South African life.

In an article titled South Africa's developing model of ReligionState relations, Jonathan D Smith (2005) articulated an emerging model for religion-state relations in the South African context by historically analysing its evolution from the colonial past through to the democratic present. Smith (2005) notes that:

[T]he formal model of religion-state relations that develops in a given country is based on three elements: the text in its Constitution (if such a document exists), legislation, and judicial interpretations of such legislation. (p. 3)

And according to Smith (2005:3), [t]he majority of countries in the world today adopt a model with some amount of separation between the domains of religion and state. Statereligion models take varying forms, depending on the particular context of each country and four of the most common forms are: (1) separate spheres of power where religion and state are separated into spheres with some type of legal power sharing between them; (2) separation with establishment wherein the state officially sanctions one form of religion, but generally allows freedom of practice to other religions; (3) strict separation wherein the state is officially secular, a model where religious groups are free to practise their beliefs in the private sphere, but religious input is not welcome in the public sphere of law and policy; (4) separation with interaction whereby the state is officially secular as it does not favour one religious group over another.

Reflecting on the role of public theology in an article titled The church and public space traversing the new South Africa (2010), Stephen W. Martin considered 'ecclesial embodiments of public theology' as reflected in the work of the Central Methodist Church and J.L. Zwane and noted that without disciplined theological reflection, public theology isolates itself. He draws on creativity of the Constitutional Court building and its layout, which embody an ongoing process of making the new South Africa based on democracy, justice and freedom out of the old, which was based on apartheid to demonstrate how public theology and politics can merge with African values:

The foyer contains a large wall built from bricks of the old prison ... [t] he foyer has seats made of tree trunks, pointing to the ancient African tradition of mediating disputes while sitting on stumps under a tree ... [t] he courtroom where hearings take place ... is decorated with cowhide, representing the significance of cattle in African traditional society. A large South African flag made of thousands of tiny beads woven together stands to the right of the Justices' seats. To the left is a window, about half a metre high, $[t]$ he Justices can see only the feet of passers-by through that window, with no idea of race, class, or gender. (Martin 2010:15)

By making consultations with religious leaders, the government was African in their approach as this resonated with imbizo, a consultative notion of elders and traditional leaders meeting to discuss community issues. Whilst staying true to African values and exercising its mandate, the South African government's consultation with religious leaders not only demonstrated their commitment to promote religious tolerance but also presented a dilemma given that some sections of the church in South Africa have a history of acting as an arm of colonialism and apartheid. The President was good and kind to religious leaders, but failed to deliver justice for the poor. According to Haynes (1996:24), colonial administrations attempted to employ religion tactically in their pursuit of political dominance. It is this dark part of South African history in church-state relations that ensures separation of religion and state although political leaders are themselves religious. ${ }^{2}$ According to Walzer (2007:156) religion creates very strong communal bonds, and the government has ensured that religious communities are strategic partners in socio-economic transformation programmes. But we have not seen a bold move to address injustices perpetrated by unscrupulous religious practioners on the poor. Given the well-documented abuses of power ${ }^{3}$ by some religious leaders, can communities trust all religious leaders to do the right thing?

\section{Faith communities play a major role in the fight against coronavirus disease 2019}

Addressing the nation on the 26th of May 2020, President Ramaphosa rightly acknowledged the role of faith communities in the fight against coronavirus and recognised religious leaders as essential workers given the role they play in providing care and counselling to distressed people. He also highlighted how religious communities had opened their facilities to provide additional shelter to abused women and children, additional healthcare facilities and distributing food to the poor - especially during the lockdown period. Despite commendable interfaith consultations and recognition of the important role played by religious communities in addressing challenges in South Africa, ${ }^{4}$ the government failed to use the

2.President Cyril Ramaphosa was the leader of the youth student Christian movement and most politicians often attend religious gatherings during their campaigns.

3.For example, see; http://www.crlcommission.org.za/complaints.html for hearings on complaints against some religious leaders who were feeding people snakes, grass and making their members drink petrol or other harmful substances.

4.It is important to mention that this process has been ongoing before COVID-19 measures, but had yielded very little in addressing abuses of power by religious leaders. 
opportunity presented by COVID-19 to address injustices and exploitation experienced by the poor within the religious sector. This also raises questions on whether these consultations were genuine or this was a ploy to placate a large section of society that was getting impatient with the lockdown. I will now highlight some of these challenges.

\section{'It is now in your hands': Can those hands be trusted?}

Announcing the easing of lockdown to level three, President Ramaphosa concluded his address to the nation ${ }^{5}$ with the words from former President Nelson Mandela, who said: 'It is now in your hands' to highlight the fact that managing the spread of coronavirus will now depend on community mobilisation and the behaviour of all people, including how business and religious communities conduct their activities. It is important that religious communities who choose to open places of worship make responsible decisions and comply with government regulations in line with values of trust expected of them.

On the 28th of May 2020702 Radio Talk Show host Eusebius Mckaiser engaged some religious leaders to find out how they were moving forward on level three lockdown. It came out that some places of worship such as the Zionist Christian Church (ZCC) and Claremont Main Road Masjid (CMRM) in Cape Town ${ }^{6}$ notified their members about not be opening for worship as announced by the President. In this talk show, Rev. Prof. Peter Storey made a remark that 'this virus likes going to church' and bluntly questioned the possibility that profit motives could be behind people who pressured the government to allow places of worship to open. Father Mathew Charlesworth SJ (Jesuit Institute of South Africa) profoundly noted that the pandemic and our response to it is not representing a crisis of faith but, rather, responses from government that do not make scientific sense present a 'crisis of reason'. Iman Dr Abdul Shahied Omar pointed out that common sense must not be abandoned, but alternative ministries, which are centred on saving lives should be explored to support the state's response to coronavirus such as making some religious facilities available as sites for testing or temporary hospitals.

In addressing the confusion of whether churches should open on level three, the Uniting Presbyterian Church in Southern Africa (UPCSA) ${ }^{7}$ circulated a precautionary statement urging those who will open to ensure compliance. It became clear that the government was treading on the religious territory very carefully. Although the President ${ }^{8}$ applauded the role of faith communities, government's engagement with religious

5.Viewed 30 May 2020, from https://citizen.co.za/business/business-news/2290360/ full-speech-ramaphosa-outlines-how-life-in-level-3-lockdown-will-look/.

6.CMRM Coronavirus (COVID-19) Advisory notice three (3), 27 May 2020, issued by CMRM Board of Governors.

7.UPCSA Leadership Guide On the Opening/ Not Opening Places of Worship. 30 May 2020.

8.Viewed 30 May 2020, from https://www.gov.za/speeches/president-cyril-ramaphosacalls-national-day-prayer-response-coronavirus-pandemic-26-mar. leaders was not pragmatically informed by science and reason, only praising faith communities and ignoring the injustices and lack of legal compliance in some sections of religious communities. For example, calling for the 30th of May 2020 to be set aside as a national day of prayer, the President had this to say:

South Africans are a people of deep faith ... the faith community is an integral part of South African life and has made a great contribution in the fight against the coronavirus.... In such a time of crisis, the noble values that are shared by all faith communities have truly come to the fore - of charity and doing good works, of helping the needy, of feeding the hungry and caring for the sick. ... Our religious leaders occupy positions of immense trust and authority in our communities, and need to play a proactive role in raising the level of public awareness around the coronavirus in their services.

A word of caution to corrupt and unscrupulous religious leaders who are motivated by greed to open places of worship on the basis of dwindling financial resources would have provided a more balanced and pragmatic approach for the government. What if some religious leaders resort to giving detergents or sanitisers to their members to drink as measures to prevent coronavirus - as we have seen in the past? I overhead that 'God will protect us in the name of Jesus' and got worried that some of us may replace scientific, medically proven measures with some pseudo-spirituality, which may compromise compliance and safety of the poor people who often worship in crowded, poorly sanitised places. Who will address these religious excesses in the context of COVID-19 if the government is shying away?

\section{Abuse of power}

The government should have ceased this opportunity to not only applaud faith communities for the 'great contribution in the fight against the coronavirus...' and displaying 'noble values' - but to also address life-denying practices by some religious leaders. Given the realisation that religious leaders occupy positions of 'immense trust and authority in our communities', it is critical that the government speaks out against abuse of such trust and authority. In the last few years the South African Commission for the Promotion and Protection of Rights of Cultural, Religious and Linguistic Communities (CRL) ${ }^{9}$ has handled a number of complaints related to church leaders. For example, on the 18th of October 2017 the Commission held hearings on 'Commercialisation of Religion E Abuse of People's Belief Systems' and raised concerns about religious leaders who fed people snakes, grass and petrol or other harmful substances, driving cars over them and spraying or pouring harmful substances over them. The commission argued that citizens 'had a right to believe as they wished, but these practices degraded their human dignity.'

There are studies that have analysed abuse of power in Christian leadership (Plantak 2017; Winter 2017) and presented strategies to effectively prevent or deal with the 9.Viewed 30 May 2020 , from http://www.crlcommission.org.za/complaints.html. 
abuse of power in different cultural contexts within Christian communities. In an article titled, 'Ethical analysis of Abuses of Power in Christian Leadership...' Plantak (2017) notes that power is an integral aspect of all types of leadership and defines 'abuse of power' as 'an inappropriate and corrupt application of power. The exercise of power becomes abusive when a person in a position of power acts in a manner that cannot be justified in terms of truth or morality (goodness, kindness, justice or obedience)' (Plantak 2017:25). It is only through life-affirming practices embodied through the values of goodness, kindness, justice and obedience that religious leaders will be valued essential workers especially given the role of spiritual care and oversight in times of distress.

The role of the church and other faith communities in spiritual and social transformation has been observed by Villa-Vicencio (2009) who acknowledged:

$[T]$ he need for faith communities to play a holistic or integrated role in society, incorporating the role of a priest and prophet plus political counsellor, in a holistic paradigm of ministry.

Religious communities play an important role in social transformation, but religion can be exploited and it is inherently a powerful tool that often succumbs to the deceit of human power. Therefore, the practices of religious leaders should be tested through the values of goodness, kindness, justice and obedience as recommended by Plantak (2017). It is only through life-affirming practices embodied through the values of goodness, kindness, justice and obedience that religious leaders will demonstrate that they are essential workers - especially given the important role of spiritual care and oversight in times of distress. Same values should also apply for political leaders; they can be good and popular, but they should also deliver on justice.

Whilst respecting religious freedom and rights enshrined in the constitution, the government should boldly step in where religious authority is abused to protect the dignity of people. For example, in Engcobo in the Eastern Cape there were brothers who killed police officers as they exchanged fire with the police in a church used for criminal activities, which included abuse of women and children. ${ }^{10}$ Financial accountability and transparency also remain a challenge for most churches. According to a circular by the UPCSA Finance Committee, congregations that qualified for Unemployment Insurance Fund (UIF) were those whose ministers were registered with the South African Revenue Services (SARS) to pay taxes. ${ }^{11}$ Such a lack of accountability exposes religious practioners to the risk of defaulting on pensions and tax returns.

Indeed, 'it is now in our hands', but how will religious leaders uphold 'authority' entrusted to them as essential workers. Will some continue to abuse trust and exploit the poor through criminal activities in the name of religion?

10.Viewed 30 May 2020 , from https://ewn.co.za/2018/02/24/cops-shoot-and-kill-7 suspects-linked-to-engcobo-police-station-killings.

11.UPCSA Finance Update circulated to all UPCSA congregations and dated 28 April 2020.
Martin Luther once retorted: 'If you preach the gospel in all aspects with exception of issues which deal specifically with your time-you are not preaching the gospel at all' (in Koch 2017:79). By redefining our world, COVID-19 also presents religious communities with an opportunity for transformation. Modern technology will play a bigger role in shaping new communities in societies mediated by a technoculture, and religious leaders need to be aware of these changing times - what Karl Barth suggested as doing theology with the Bible in one hand and the daily newspaper in the other (Yates 2017). Reading the signs of the times will require more accountability, transparency and justice. This is the ideal leadership for transformation and the organic church - both virtual and real:

Church is not an institution or a space for religious gathering; rather Church is an event that happens in particular contexts in the life of communities longing for love, freedom, dignity, justice, acceptance and flourishing of life ... communities [...] experience $[\ldots]$ violence of dominant power relations, morality and religious dogmas and practices, the Church happens as counter-cultural experience that disrupts the logic of the prevailing order $\ldots$ and empowers the communities ... Church as an event is more is more than a disruptive event; it is also a creative event as it midwifes the birth of alternative faith communities that live out of the foretaste of the reign of God. (Sudipta FB post 22 May 2020)

\section{Recommendations}

It is critical that government engagement with religious leaders be pragmatically informed by science and reason. Government should remain pro-poor and place the safety of the people ahead of financial gains. The opening or no opening of places of worship is not about 'freedom of worship' - but it is about health and safety in the face of coronavirus. Spirituality does not have to replace reason and the following should be recommended:

- Authorities should ensure that religious gatherings are for purposes of prayer and life-affirming humanitarian activities centered on values of goodness, kindness, justice and obedience as means to work towards fullness of life and restoration of hope and dignity for distressed people. Exploitation of the poor should not be tolerated.

- In demonstrating that the decision to open up churches on level three was not ill-advised, government and religious leaders should take responsibility to protect lives and ensure compliance with all the guidelines and standards developed to save lives. Anglican Archbishop Thabo Makgoba (Church Times 2020) pointed out: 'COVID-19 will test as never before [the] capacity as a Church to innovate and share with one another' and beyond innovation, 'compliance' and 'reason' will be critical.

- In line with government regulations and values of trust expected of religious leaders, those who choose to open their places of worship ${ }^{12}$ should be held accountable for

12.It is important to keep remembering that religious gatherings in South Korea and Germany were places of high transmissions for the spread of coronavirus. Paying attention to these statistics demonstrates reason and responsible leadership. 
what happens in places of worship under their care. This is critical - given that ministry or mission is not just about worship - but provision of facilities for testing and temporal hospitals could be alternative and reasonable service to people in the context of COVID-19 crisis.

- Lastly, to protect poor communities from being exploited by unscrupulous religious leaders, government should not shy away from its responsibility to ensure that religious organisations operate in compliance with the SARS regulations, which guide public benefit organisations.

\section{Conclusion}

This article examined the South African government's engagement with religious leaders and highlighted the implications of these relations in the context of the South African government's response to COVID-19. By critically engaging a public theology of 'immense trust and authority' assigned to religious leaders, the article identifies 'separation with interaction' as a model, which informs the South African government's state-religion engagement. Although this model is constitutional and promotes religious freedoms, the article identified the government's failure to act decisively on religious leaders who exploit the poor as a major obstacle to socio-economic and religious transformation. The dark part of South African history was identified as a dilemma to church-state relations in South Africa and amongst some recommendations, it is suggested that life-affirming practices of religious leaders should be monitored by religious councils and tested through the values of goodness, kindness, justice and obedience as well as contextualised theological consensus based on the great commandments as a demonstration that they are essential workers who have an important transformational role to play in the post-COVID-19 context.

\section{Acknowledgements}

The author would like to acknowledge the generous contributions for the participation in eThekwini Presbytery WhatsApp group conversations and Facebook interactions and statements issued by the Uniting Presbyterian Church in Southern Africa (UPCSA) during the COVID-19 lockdown period.

\section{Competing interests}

The author solemnly declares that he has no financial or personal relationship(s), which may have inappropriately influenced him in writing this article.

\section{Author's contributions}

The author contributed to this work individually.

\section{Ethical consideration}

While the ethical clearance was sought to conduct research on COVID-19, this article did not involve data which needed ethical procedures as it relied on literature review and media statements.

\section{Funding information}

This research received no specific grant from any funding agency in the public, commercial, or not-for-profit sectors.

\section{Data availability statement}

Data sharing is not applicable to this article as no new data were created or analysed. Data which were collected through a questionnaire cleared by the research committee are yet to be received and analysed.

\section{Disclaimer}

The views and opinions expressed in this article are those of the author and do not necessarily reflect the official policy or position of any affiliated agency of the author.

\section{References}

Desmond, T., 2000, 'No room for compromise: South African Churches and apartheid', in Innovation, pp. 14-18.

Dodge, M. \& Kitchin, R., 2001, Mapping cyberspace, Routledge, London.

ENCA, 2020, Level 3 regulations: Ramaphosa lifts lid on religious gatherings, MSN News, viewed 27 May 2020, from https://www.msn.com/en-za/news/national/ level-3-regulations-ramaphosa-lifts-lid-on-religious-gatherings/arBB14CL6Z?ocid=spartandhp.

Gibson, W 1984, Neuromancer, Grafton, London.

Haynes, J., 1996, Religion and Politics in Africa, Zed Books, London.

Jita, M. 2020, Finance Committee update to all UPCSA congregations, Email circulated within the UPCSA dated 28 April 2020.

Koch, H., 2017, Contemporary missiology: Concepts and contextualization of mission in context and the Cape Town commitment, Koch Publishing, UK.

Kunzmann, R., 2002, The self-concept of spinally-injured people: The role of frequent internet communication within cyber-communities, University of Pretoria, Pretoria.

Lord, A.M., 2002, 'Virtual communities and mission', Evangelical Review of Theology 26(3), 196-207.

Makgoba, T., 2020, Coronavirus - Updated guidelines from the Archbishop - As at Thursday April 2-17 March 2020. viewed 24 March 2020, Available at: https:// anglicanchurchsa.org/coronavirus-updated-guidelines-from-the-archbishop/.

Martin, S.W., 2010, The Church and public space in South Africa, viewed 24 May 2020 from https://www.academia.edu/33485974/MartinChurch_and_Public_Space_ in_South_Africa.pdf.

Mckaiser, E., 2020, 702 Talk Radio Show FB Live Streaming, viewed 02 June 2020, from https://omny.fm.

Mdakane, M., 2017, Commercialization of Religion and Abuse of People's Belief systems, CRL Rights Commission Report, viewed 30 May 2020, from https://pmg. org.za/page/CRL\%20Rights?via=homepage-feature-card.

Mpetsheni, L., 2020, Leadership Guide On the Opening or Not Opening of Worship. Email circulated within the UPCSA dated 30 May 2020

Nicolo, L., 2020, What Covid did for Zoom and what Zoom did for Covid, viewed 27 May 2020, from https://medium.com/swlh/what-covid-19-did-for-zoomus-what-zoomus-did-for-covid-19-c3b766a6c723.

Nocolo, 2020, What COVID-19 Did for Zoom. us \& What Zoom. us did for COVID-19, 15 March 2020, viewed 02 June 2020, from https://medium.com/swlh/whatcovid-19-did-for-zoom-us-what-zoom-us-did-for-covid-19-c3b766a6c723.

Pitjeng, R., 2020, Cops shoot and kill 7 suspects linked to Ngcobo police station killings, viewed 30 May 2020, from https://ewn.co.za/2018/02/24/cops-shoot-and-kill-7suspects-linked-to-engcobo-police-station-killings

Plantak, Z., 2017, 'Ethical analysis of abuses of power in christian leadership - A case atudy of "kingly power" in the seventh-day adventist church', Dissertations, 1646 viewed from https://digitalcommons.andrews.edu/dissertations/1646.

Ramaphosa, C.M., 2020, Outlining of Leve3, viewed 30 May 2020, from https:// citizen.co.za/business/business-news/2290360/full-speech-ramaphosa-outlineshow-life-in-level-3-lockdown-willlook/.

Ramaphosa, C.M. n.d., Escalation of Measures to combat coronavirus COVID-19 pandemic, viewed 30 May 2020, from: https://www.gov.za/speeches/presidentcyril-ramaphosa-escalation-measures-combat-coronavirus-covid-19-pandemic23-mar.

Ramaphosa, C.M., n.d., Call for a day of prayer on Coronavirus COVID-19, 26 May 2020, viewed 28 May 2020, from https://www.gov.za/speeches/presidentcyrilramaphosa\%26 May. 
Ramaphosa, C.M., n.d., South Africa's response to Coronavirus COVID-19 pandemic viewed 13 May 2020, from https://www.gov.za/speeches/presidentcyrilramaphosa-south-africas-response-coronavirus-covid-19-pandemic-13may-2020.

Rheingold, H., 1993, The virtual community: Homesteading on the electronic frontier, Addison-Wesley Publishing, New York, NY.

Rock, D., 2008, 'SCARF: A brain-based model for collaborating with and influencing others', Neuroleadership Journal 1, 1-9.

Ryan, M.L., 1999, Cyberspace textuality: Computer technology and literary theory Indiana University Press, Indiana, USA.

Smith, J.D., 2005, South Africa's developing model of Religion-State relations, viewed 27 May 2020, from www.academia.edu.

South African Government, 2020, Call for a day of prayer on Coronavirus COVID-19, viewed 26 May 2020, from https://www.gov.za/speeches/president-cyrilramaphosa\%
Strate, L., Jacobson, R.L. \& Gibson, S., 2003, Communication and cyberspace: Social interaction in an electronic environment, Hampton Press, Creskill, NJ.

Sudipta, S., 2020, Face Book post dated 22 May 2020, viewed 24 May 2020, from https://www.facebook.com/sudiptasinghcni.

Villa-Vicencio, C., 2009, 'Towards a transformed society' Diakonia Council of Churches annual lecture, 13 August, 2009 under the theme The church and social transformation: Prophet, priest and political voice, p. 6

Walzer, M., 2007, Thinking politically: Essay in political theory, Yale University, USA

Winter, M.J., 2017, An analysis of the abuse of power by leaders in Christian organisations: Cultural comparisons from Canada, Germany and South Africa, University of South Africa, Pretoria,

Wise, J., 2014, The social church: A theology of digital communication, Moody Publishers, Chicago, IL.

Yates, J., 2017, 'The social Christian: A theological exploration of social media', The Church Marketing that Sucks, 06 November, p. 3. 